\title{
Article \\ Mechanical Behavior of Bi-Layer and Dispersion Coatings Composed of Several Nanostructures on Ti Substrate
}

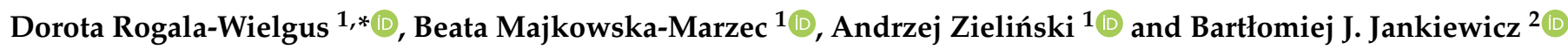 \\ 1 Division of Biomaterials Technology, Faculty of Mechanical Engineering and Shipbuilding, \\ Gdansk University of Technology, 11 Narutowicza Street, 80-233 Gdańsk, Poland; \\ beata.majkowska@pg.edu.pl (B.M.-M.); andrzej.zielinski@pg.edu.pl (A.Z.) \\ 2 Institute of Optoelectronics, Military University of Technology, Gen. S. Kaliskiego 2, \\ 00-908 Warszawa, Poland; bartlomiej.jankiewicz@wat.edu.pl \\ * Correspondence: dorota.wielgus@pg.edu.pl; Tel.: +48-534-897-893
}

Citation: Rogala-Wielgus, D.;

Majkowska-Marzec, B.; Zieliński, A.; Jankiewicz, B.J. Mechanical Behavior of Bi-Layer and Dispersion Coatings Composed of Several Nanostructures on Ti Substrate. Appl. Sci. 2021, 11, 7862. https://doi.org/10.3390/ app11177862

Academic Editor: Elzbieta Pach

Received: 30 July 2021

Accepted: 24 August 2021

Published: 26 August 2021

Publisher's Note: MDPI stays neutral with regard to jurisdictional claims in published maps and institutional affiliations.

Copyright: (c) 2021 by the authors. Licensee MDPI, Basel, Switzerland. This article is an open access article distributed under the terms and conditions of the Creative Commons Attribution (CC BY) license (https:/ / creativecommons.org/licenses/by/ $4.0 /)$.

\begin{abstract}
Three coatings suitable for biomedical applications, including the dispersion coating composed of multi-wall carbon nanotubes (MWCNTs), MWCNTs $/ \mathrm{TiO}_{2}$ bi-layer coating, and MWCNTs$\mathrm{Cu}$ dispersion coating, were fabricated by electrophoretic deposition (EPD) on Ti Grade II substrate. Optical microscopy, scanning electron microscopy, energy-dispersive X-ray spectroscopy, and nanoindentation were applied to study topography, chemical, and phase composition, roughness, hardness, Young's modulus, plastic, and elastic behavior. The results showed that the best mechanical properties in terms of biomedical application were achieved for the MWCNTs coating with titania outer layer. Nevertheless, both the addition of nanocopper and titania improved the mechanical resistance of the base MWCNTs coating. Compared to our previous experiments on Ti13Nb13Zr alloy, a general tendency is observed to form more homogenous coatings on pure metal than on the alloy, in which chemical and phase compositions are more complex.
\end{abstract}

Keywords: carbon nanotubes; coatings; nanohardness; Young's modulus

\section{Introduction}

The carbon nanotubes (CNTs) belong to highly promising functional materials due to their extraordinary properties as electrical semiconductivity, high mechanical stiffness, tensile strength, high elasticity, significant thermal conductivity, and, in certain conditions, superconductivity [1,2]. The CNTs may appear in different forms as single-, double-, and multi-wall carbon nanotubes (MWCNTs) [3], nanohorns, and nanobuds [1]. They find applications in different fields as many branches of nanotechnology, nanomedicine, membranes and biosensors, electrochemical, piezoelectric and gas sensors, capacitors, and transistors in electronics [3], and high-performance batteries [4,5]. In particular, in medicine, they are proposed for drug targeting, cancer diagnosis, and treatment, as antibacterial and antifungal structures [2], and as gene carriers [6].

The most popular development direction of CNTs is their application in multi-component materials. The typical recent examples include cellulose - CNTs for methylene adsorption [7], nitrogen-doped graphene-CNTs for microwave absorption [8], polypyrrole-CNTs for storage devices [9], $\mathrm{ZnO}-\mathrm{CNTs}$ dispersed in PU for better anti-corrosion resistance [10], cement [11,12], and Al alloy reinforced with CNTs [13]. The specific optical and electrical properties, high specific surface area, high chemical activity, and significant mechanical behavior are the reasons for the development of a great number of such composite materials $[14,15]$.

CNTs can also form coatings, layers, or films. They have been, rather seldomly, proposed as single coating, e.g., to enhance the adsorption of albumins on $\mathrm{Ti}$ [16], in condensation heat transfer systems [17], to enhance biotribological resistance of Ti alloy [18], to mitigate biofouling [19], and in environmental protection [20]. However, they 
are more often used as one of the layers in sandwich (hybrid) coatings, or as one of the components of the coating. The most frequently studied composite coatings are those based on CNTs and CNTs reinforced hydroxyapatite (HAp) [21-23], and HAp substituted by ( $\mathrm{Sr}+\mathrm{Mg}+\mathrm{Zn})$ [24], Hap-collagen-MWCNTs [25], and Hap-titanium-CNTs [26]. Other research focused on composite coatings such as tantalum oxide-CNTs [27], collagenCNTs [28], collagen-CNTs-acrylic acid [29], CNTs-polysiloxane [30], and $\mathrm{Al}_{3} \mathrm{Ti}-\mathrm{Cu}-\mathrm{SiC}-$ CNTs [31]. As concerns the noble metals, it is important to note the electrodes obtained by atomic layer deposition and composed of MWCNTs, $\mathrm{TiO}_{2}$, and $\mathrm{Pt}$ [32]. The possibility of interaction of $\mathrm{Ni}, \mathrm{Ti}, \mathrm{Pd}$, and $\mathrm{Au}$ with CNTs was shown for different forms of carbon nanotubes [33]. Nanochitosan capped gold nanoparticles were also obtained [34]. The important role of nanogold in the immobilization of proteins associated with SARS-CoV-2 was shown by Yokohama et al. $[35,36]$.

The use of noble or semi-noble metals is justified by their antibacterial properties. However, if silver is assumed to be a safe element to human cells [37], the higher potential risk comes from the use of nanocopper than two-valent copper ions, related to different mechanisms of their toxic effects [38]. On the other hand, rGO (reduced graphene oxide)nanoCu scaffolds demonstrated high antibacterial efficiency [39]. The nanogold was shown to eliminate pathogenic bacteria and even cancer cells [40], but no data about the side effects of this element are known.

The research studies described in this article are aimed at determining several properties of some new promising multi-component systems for medicine, which are based on MWCNTs. The titanium dioxide is added to the MWCNTs-based coating to enhance its mechanical behavior, while nanocopper is implemented to create the antibacterial activity of titanium implants. The MWCNTs-titanium oxide systems were developed for different purposes as nanocomposites obtained by sol-gel technique [41], by high energy ball milling [42], and by atomic layer deposition of titania on MWCNTs [43]. Nanocopper was a component of several coatings: $\mathrm{HAp}$-nanoCu [44,45] and polyelectrolyte-nanoCu [46]. However, there is no sufficient research or knowledge on such material systems, which are potentially promising in the development of antibacterial, bioactive, and mechanically strong coatings for titanium implants.

\section{Materials and Methods}

\subsection{Materials}

The Ti Grade II (EkspresStal, Luboń, Poland) was used as a substrate. Specimens in form of $40 \mathrm{~mm}$ in diameter and $4 \mathrm{~mm}$ thick slices were cut from the rod and divided into quarters using a precision cutter (Brillant 220, ATM GmbH, Mammelzen, Germany). The surface was ground using abrasive paper $\mathrm{SiC}$ up to grit \# 800 on a metallographic grinding machine (Saphir 330, ATM GmbH, Mammelzen, Germany). Then, specimens were rinsed with acetone (Chempur, Piekary Ślaskie, Poland), distilled water, dried in the air, and pickled in 5\% HF (Chempur, Piekary Ślaskie, Poland) for $30 \mathrm{~s}$ to remove oxide layers from the surface, and finally rinsed with distilled water.

The multi-wall carbon nanotubes (MWCNTs) had an outer diameter of 10-15 nm, an inner diameter of 2-6 nm, a length of 1-10 $\mu \mathrm{m}$, and the number of walls 3-15 (3D-Nano, Krakow, Poland). Nanocopper (nanoCu) had a mean grain size of $80 \mathrm{~nm}$ (Hongwu International Group Ltd., Guangzhou, Guangdong, China). Titanium dioxide $\left(\mathrm{TiO}_{2}\right)$ of rutile structure (3D-Nano, Krakow, Poland), possessed a grain size in the range of 1 to $2 \mathrm{~nm}$.

\subsection{Fabrication of the Bi-Layer MWCNTs/TiO $\mathrm{O}_{2}$ Coating and MWCNTs_Cu Dispersion Coating}

The electrophoretic deposition (EPD) method was used to prepare coatings, for which synthesis parameters are shown in Table 1. The Ti Grade II substrate was used as an anode and stainless steel as a counter-electrode for the MWCNTs coating, and inversely for both other coatings. The electrodes were placed parallel to each other within a distance of $5 \mathrm{~mm}$ and connected to the DC power source (MCP/SPN110-01C, Shanghai MCP Corp., Shanghai, China). 
Table 1. Parameters of synthesis of coatings.

\begin{tabular}{|c|c|c|c|c|c|}
\hline Coating & Substrate & Deposited Materials & $\begin{array}{l}\text { Content of Component } \\
\text { in a Bath (wt. pct.) }\end{array}$ & $\begin{array}{l}\text { EPD Time } \\
\text { (min) }\end{array}$ & $\begin{array}{c}\text { EPD Voltage } \\
\text { (V) }\end{array}$ \\
\hline MWCNTs & Ti Grade II & MWCNTs & 0.25 & 1 & 20 \\
\hline & & (I) MWCNTs & 0.25 & 1 & 20 \\
\hline MVCNIS_I1U 2 & Ti Grade II & (II) $\mathrm{TiO}_{2}$ & 0.30 & 4 & 50 \\
\hline MWCNTs/Cu & Ti Grade II & MWCNTs + nanoCu & $\begin{array}{c}0.25 \\
0.0125\end{array}$ & 4 & 50 \\
\hline
\end{tabular}

The EPD process was conducted at parameters selected based on the preliminary studies. The bi-layer coating MWNCTs_TiO ${ }_{2}$ was prepared in two steps. First, the electrophoretic suspension of $0.1 \mathrm{~g}$ MWCNTs in $40 \mathrm{~mL}$ of distilled water was prepared and the EPD process on Ti Grade II substrate proceeded (designation: MWCNTs). Second, the same samples were deposited in suspension consisted of $0.15 \mathrm{~g} \mathrm{TiO}_{2}$ dispersed in $50 \mathrm{~mL}$ of isopropanol together with $0.5 \mathrm{~mL}$ of surfactant -Polysorbate 20 (Tween 20, Sigma-Aldrich, Poznan, Poland).

To prepare the dispersion coating MWCNTs_Cu, $0.1 \mathrm{~g}$ of MWCNTs, $0.005 \mathrm{~g}$ of nanoCu, and $0.5 \mathrm{~mL}$ of Polysorbate 20 were dispersed in $40 \mathrm{~mL}$ of distilled water and deposited using the EPD method on Ti Grade II substrate.

\subsection{Structure and Morphology}

To study the surface topography, the optical microscope (VHX Keyence, Keyence International (Belgium) NV/SA, Mechelen, Belgium) was used. The average roughness index $S_{a}$ values were estimated based on 512 lines made in the area of approximately $150 \mu \mathrm{m} \times 140 \mu \mathrm{m}$. Additionally, the atomic force microscopy (NaniteAFM, Nanosurf AG, Liestal, Switzerland) at a non-contact mode of testing with a $20 \mathrm{nN}$ force was applied for the same purpose. Tests were made on the surface of dimensions $50 \mu \mathrm{m} \times 50 \mu \mathrm{m}$ and the $S_{a}$ parameter was estimated based on 256 lines (time for a single line of $2 \mathrm{~s}$ ).

The specimens' surfaces and cross-sections were observed using a high-resolution scanning electron microscope (SEM) (JSM-7800F, JOEL, Tokyo, Japan) with a LED detector, at $5 \mathrm{kV}$ acceleration voltage.

The chemical composition of the coatings was investigated by the X-ray energy dispersive spectrometer (EDS) (Octane Elite 25, EDAX Ametek, Berwyn, PA, USA).

\subsection{Nanoindentation Studies}

Nanoindentation tests were performed with the NanoTest ${ }^{\mathrm{TM}}$ Vantage (Micro Materials, Wrexham, Great Britain) equipment, except for the MWCNTs reference coating which was measured with the nanoindentation tester $\mathrm{NHT}^{3}$ (Anton Paar, Buchs, Switzerland), equipped with an optical microscope. All samples were tested using a Berkovich threesided pyramidal diamond probe. The combined samples: the $\mathrm{MWCNTs} / \mathrm{TiO}_{2}$ and the MWCNTs_Cu coatings were measured in twenty-five $(5 \times 5)$ points, while the MWCNTs reference coating was tested in the best place, based on optical microscopy observation. The measurements were carried out according to a test method following the ISO 14577 standard (the maximum applied force: $10 \mathrm{mN}$, the loading and unloading rate: $20 \mathrm{~s}$, the dwell period at maximum load: $10 \mathrm{~s}$ ). The distances between the subsequent indents were $20 \mu \mathrm{m}$. The load-displacement curve was determined by the Oliver and Pharr method, and surface hardness $(\mathrm{H})$, reduced Young's modulus (Er), elastic and plastic deformation energies were calculated using the integrated software. Young's modulus (E) parameter was estimated based on the reduced Young's modulus (Er) parameter and the Poisson's ratio (v). Assuming the MWCNTs $/ \mathrm{TiO}_{2}$ and MWCNTs_Cu coatings as unidirectional composite materials, the values of $\mathrm{v}, \mathrm{E}$, and $\mathrm{H}$ parameters were calculated from the HalpinTsai (H-P) model, explained in our previous publication [47]. The volume fraction was calculated according to [48] and assuming densities of $2.10 \mathrm{~g} / \mathrm{cm}^{3}$ [49], $4.23 \mathrm{~g} / \mathrm{cm}^{3}$ [50], and $8.94 \mathrm{~g} / \mathrm{cm}^{3}$ [51] for MWCNTs, $\mathrm{TiO}_{2}$, and nanoCu, respectively. 
The v values of 0.254 and 0.251 were assessed for the MWCNTs/ $\mathrm{TiO}_{2}$ and MWCNTs_Cu coating, respectively.

\section{Results}

\subsection{Structure and Morphology}

The surface topographies of the MWCNTs, MWCNTs/TiO 2 , and MWCNTs_Cu coatings are shown in Figure 1. The reference MWCNTs coating is characterized with high ups and downs, while for the MWCNTs $/ \mathrm{TiO}_{2}$ and the MWCNTs_Cu coatings, the roughness is higher, but the distance between ups and downs is lower. The surface of the MWCNTs_Cu coating is significantly leaned - the left side of the sample is higher than the other, which could be the reason for an unevenly put force during the grinding process or the difference in the MWCNTs_Cu coating thickness on both sides of the sample. The values of the roughness parameter $\left(S_{a}\right)$ calculated both with the optical microscope and the atomic force microscope are demonstrated in Table 2. It could be observed that the $S_{a}$ parameter is higher for all surfaces when using the atomic force microscopy, which could be attributed to the use of the non-contact mode AFM and thus lower accuracy.

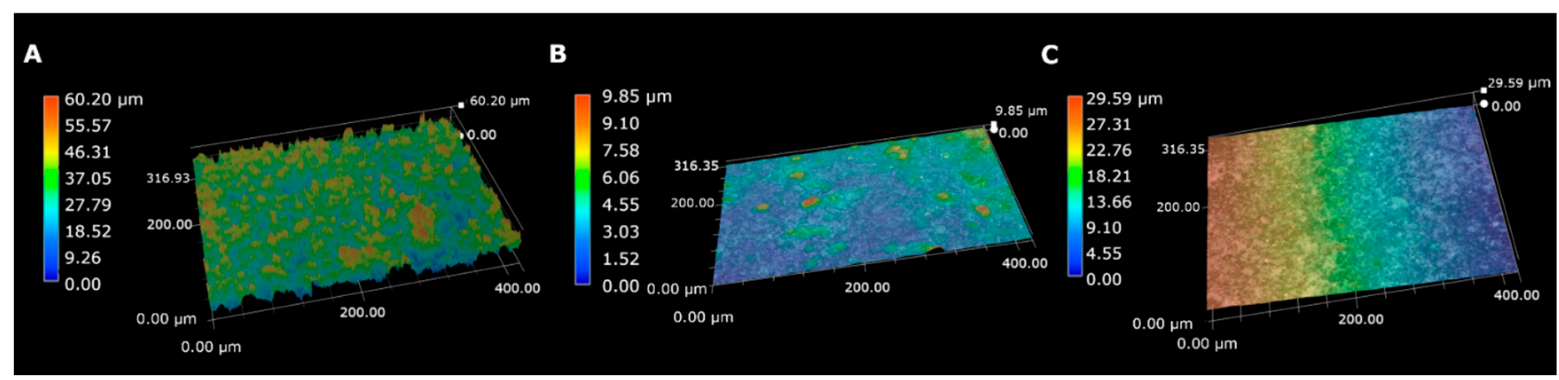

Figure 1. Surface topography based on optical microscopy tests for (A) the MWCNTs coating, (B) the $\mathrm{MWCNTs} / \mathrm{TiO}_{2}$ coating, and (C) the MWCNTs_Cu coating.

Table 2. Surface roughness of the deposited coatings.

\begin{tabular}{ccc}
\hline Sample & $\begin{array}{c}\text { Roughness } \mathbf{S}_{\mathbf{a}} \text { Based on Optical } \\
\text { Microscopy Tests }(\mu \mathbf{m})\end{array}$ & $\begin{array}{c}\text { Roughness } \mathbf{S}_{\mathbf{a}} \text { Based on Atomic } \\
\text { Force Microscopy Tests }(\boldsymbol{\mu m})\end{array}$ \\
\hline MWCNTs & $0.29^{*}$ & $0.353 \pm 0.107$ \\
MWCNTs/TiO & $0.56^{*}$ & $1.033 \pm 0.107$ \\
MWCNTs_Cu & $0.36^{*}$ & $0.495 \pm 0.034$ \\
\hline
\end{tabular}

* the experimental error has been estimated as less than $0.05 \mu \mathrm{m}$.

Figure 2 shows the AFM images for tested surfaces, confirming the roughness Sa parameter values shown in Table 2. The surface of the MWCNTs/ $\mathrm{TiO}_{2}$ demonstrates the highest ups and downs, which is caused by the $\mathrm{TiO}_{2}$ agglomerates deposited on the MWCNTs surface, while the MWCNTs surface is the smoothest, as assumed.

Figure 3 demonstrates the SEM images of the surface topography of the MWCNTs, MWCNTs $/ \mathrm{TiO}_{2}$, and MWCNTs_Cu coatings at different resolutions. The surface of the MWCNTs coating shows uniformly distributed carbon nanotubes. There are light points/areas for high ups, as demonstrated in Figure 1A, supposedly places where the coating is thicker. There are many agglomerates on the combined $\mathrm{MWCNTs} / \mathrm{TiO}_{2}$ and $\mathrm{MWC}$ NTs_Cu coatings, however the structure of agglomerates is different. The $\mathrm{MWCNTs} / \mathrm{TiO}_{2}$ contains uniformly positioned angular particles of $\mathrm{TiO}_{2}$, which adhere to the surface of the MWCNTs coating, while the Cu agglomerates in the MWCNTs_Cu coating are built into the MWCNTs structure. Therefore, they are almost invisible, but nevertheless influence mechanical properties of the coating, as previously observed in [47]. The areas, where the SEM image of the MWCNTs_Cu coating is blurred, are probably spaces in which the cracks of the MWCNTs coating occur. 
A

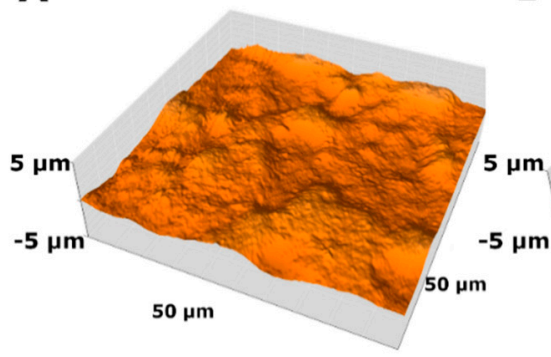

B

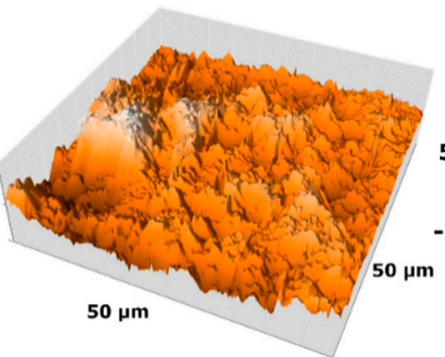

C

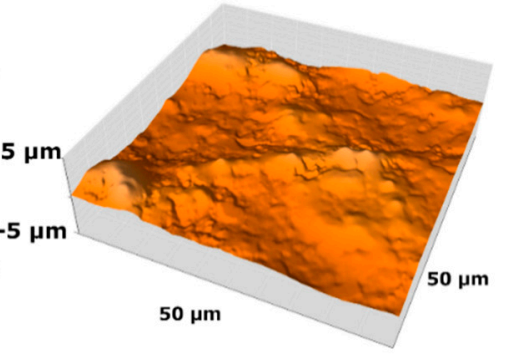

Figure 2. Surface topography based on atomic force microscopy tests for (A) the MWCNTs coating, (B) the $\mathrm{MWCNTs} / \mathrm{TiO}_{2}$ coating, (C) the MWCNTs_Cu coating.

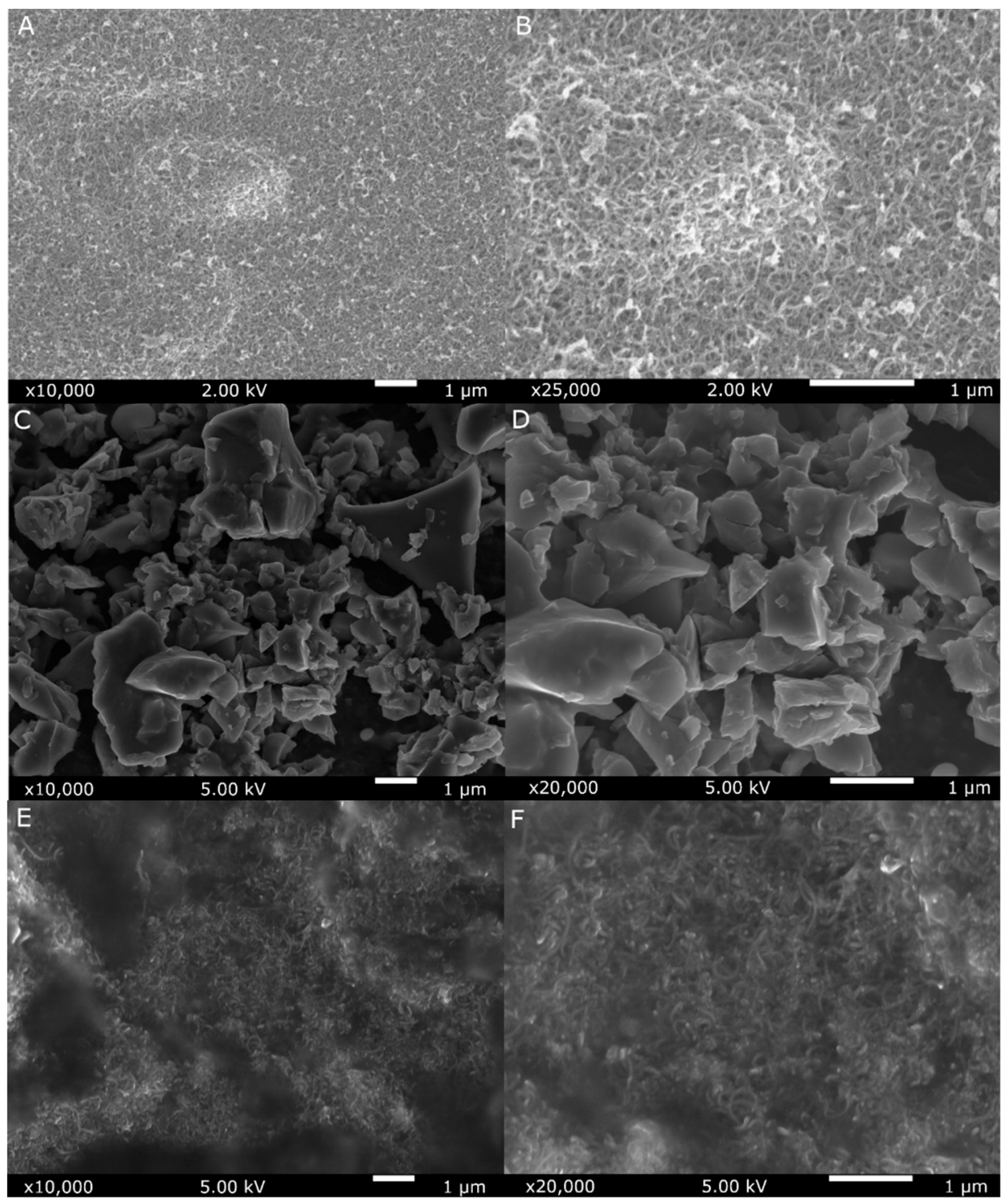

Figure 3. SEM surface topography of the MWCNTs coating (A,B), the $\mathrm{MWCNTs} / \mathrm{TiO}_{2}$ bi-layer coating $(\mathbf{C}, \mathbf{D})$, and the MWCNTs_Cu dispersion coating $(\mathbf{E}, \mathbf{F})$ at different resolutions.

The EDS spectra of the examined coatings are shown in Figure 4, confirming the appearance of the MWCNTs, MWCNTs/ $\mathrm{TiO}_{2}$, and MWCNTs_Cu coatings. There are also present some impurities (silicon, chlorine, sodium, and fluorine) that result from the samples preparation. 

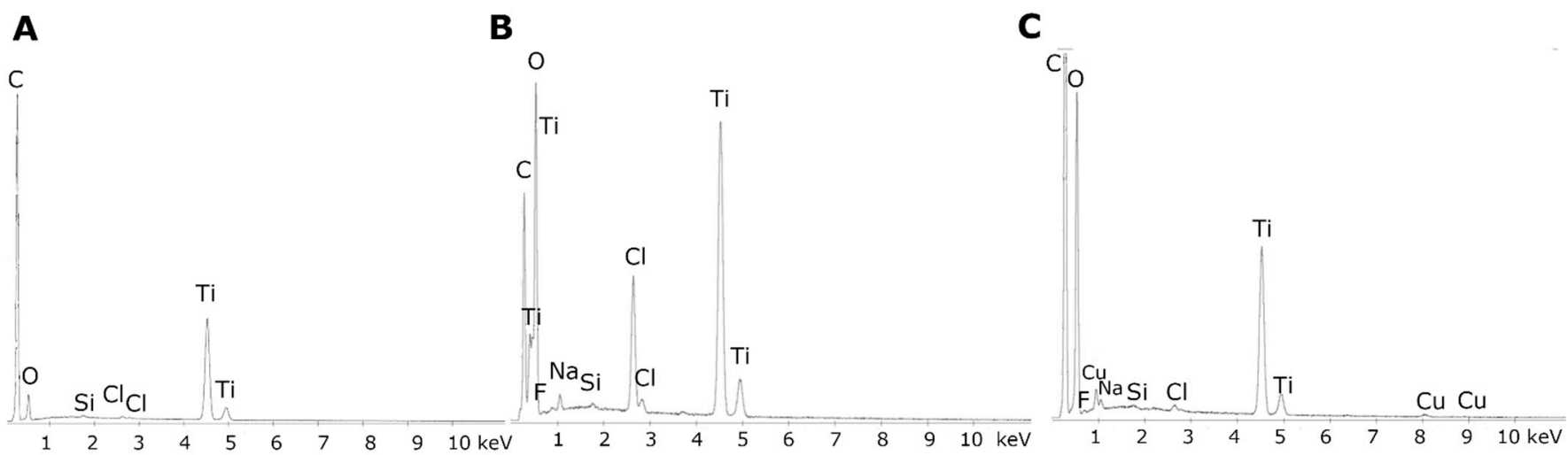

Figure 4. EDS spectra of the (A) MWCNTs reference, (B) $\mathrm{MWCNTs} / \mathrm{TiO}_{2}$ bi-layer coating, and (C) MWCNTs_Cu dispersion coating.

Moreover, the ASTM D3359-97 pressure-sensitive tape test was carried out on every single coating to check the thickness and the adhesion to the substrate. None of the examined coatings was removed during the test, which gives us valuable information of significantly strong coatings' adhesion to the Ti grade II substrate.

\subsection{Nanoindentation Studies}

The results of the nanoindentation test are illustrated as the load-displacement hysteresis curves in Figure 5. There are three stages distinguished in the nanoindentation test, which are pointed in the graph. Firstly, the increasing curve shows the force raising during the test until the maximum load is achieved. Secondly, the horizontal line demonstrates the pause, where the probe is stabilized at maximum depth. The third stage is the result of temperature drift, adjusted at the end of the nanoindentation measurement. The displacement, and thus maximum indent depth, was observed for the MWCNTs coating. Both the metal and metallic oxide additions to the MWCNTs based coating made it harder, as confirmed by mechanical properties (Table 3).

A

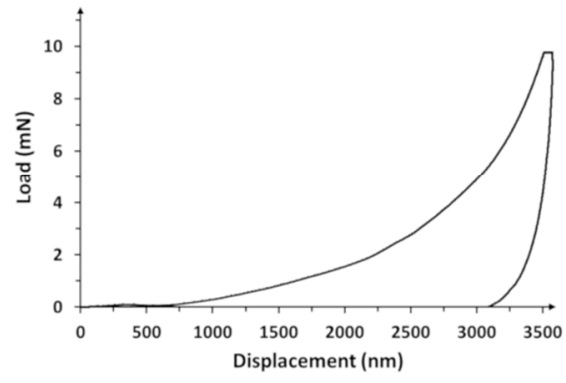

B

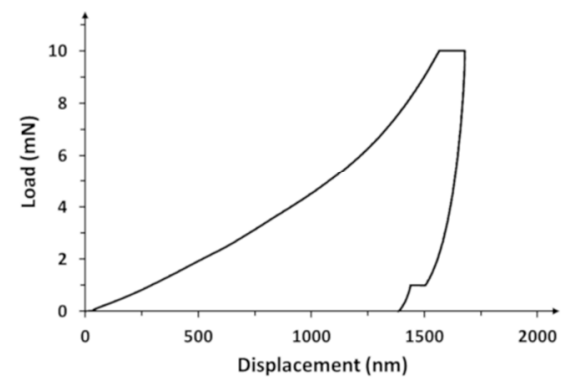

C

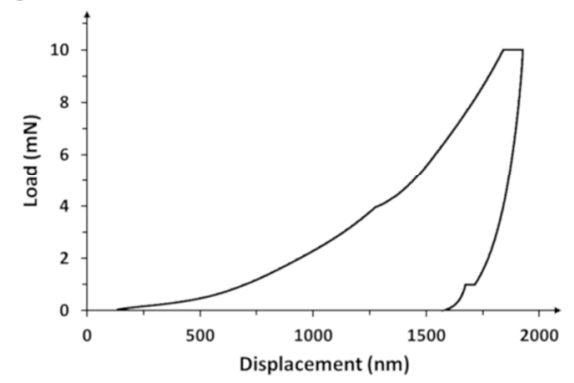

Figure 5. Nanoindentation load-displacement curves obtained for (A) the MWCNTs coating, (B) the MWCNTs/TiO 2 coating, and (C) the MWCNTs_Cu coating.

Table 3. Mechanical properties and maximum indent depth for the substrate and tested coatings.

\begin{tabular}{ccccccc}
\hline Sample & $\begin{array}{c}\text { Nanohardness } \\
\mathbf{H}(\mathrm{GPa})\end{array}$ & $\begin{array}{c}\text { Reduced Young's } \\
\text { Modulus E } \mathbf{( G P a )}\end{array}$ & $\begin{array}{c}\text { Young's } \\
\text { Modulus E } \\
\mathbf{( G P a )}\end{array}$ & $\begin{array}{c}\text { Maximum } \\
\text { Indent } \\
\text { Depth } \mathbf{h}_{\text {max }}(\boldsymbol{\mu m})\end{array}$ & $\begin{array}{c}\text { Plastic } \\
\text { Deformation } \\
\text { Energy (nJ) }\end{array}$ & $\begin{array}{c}\text { Elastic } \\
\text { Recovery } \\
\text { Energy (nJ) }\end{array}$ \\
\hline MWCNTs $^{1}$ & $0.032 \pm 0.0003$ & $4.5 \pm 0.05$ & $3.41 \pm 0.03$ & $3.58 \pm 0.04$ & $7.06 \pm 0.07$ & $0.958 \pm 0.0096$ \\
${\text { MWCNTs } / \mathrm{TiO}_{2}}$ & $0.183 \pm 0.0572$ & $13.4 \pm 3.20$ & $10.11 \pm 2.42$ & $1.55 \pm 0.28$ & $5.01 \pm 0.87$ & $0.644 \pm 0.0664$ \\
MWCNTs_Cu & $0.079 \pm 0.0354$ & $4.7 \pm 2.40$ & $3.51 \pm 1.84$ & $2.55 \pm 0.69$ & $19.23 \pm 6.83$ & $6.821 \pm 2.0237$ \\
\hline
\end{tabular}


Table 3 demonstrates the mean values and standard deviations of several mechanical properties of the MWCNTs, MWCNTs $/ \mathrm{TiO}_{2}$, and MWCNTs_Cu coatings. The hybrid and composite coatings have higher hardness and Young's modulus, and lower maximum indent depth compared to the reference MWCNTs coating, as the addition of nanoceramics and nanometals, in general, improves mechanical properties. However, we can observe the nanohardness increase when Young's modulus decreases (regarding the reference MWCNTs coating), differently than in our previous research [47], in which the same coatings have been deposited on $\mathrm{Ti}$ alloy substrate. The mechanical properties of the MWCNTs_Cu coating are pretty close to the reference sample, except plastic and elastic properties, while different for the MWCNTs $/ \mathrm{TiO}_{2}$ coating.

The elastic recovery and plastic deformation energies are also shown by an area under load-displacement curves during the nanoindentation test.

Figure 6 shows the comparison of elastic recovery and plastic deformation energy of the examined coatings. The MWCNTs_Cu coating was the most both plastically and elastically deformed, comparing to the others. It can be attributed to the nanoCu presence in the crossover sections of carbon nanotubes, which influences the coating's properties, whereas the MWCNTs $/ \mathrm{TiO}_{2}$ coating achieved better properties. After the nanoindentation test, the material was the least deformed both plastically and elastically, even less than the reference sample, which was certainly caused by hard $\mathrm{TiO}_{2}$ particles strengthening the MWCNTs coating.

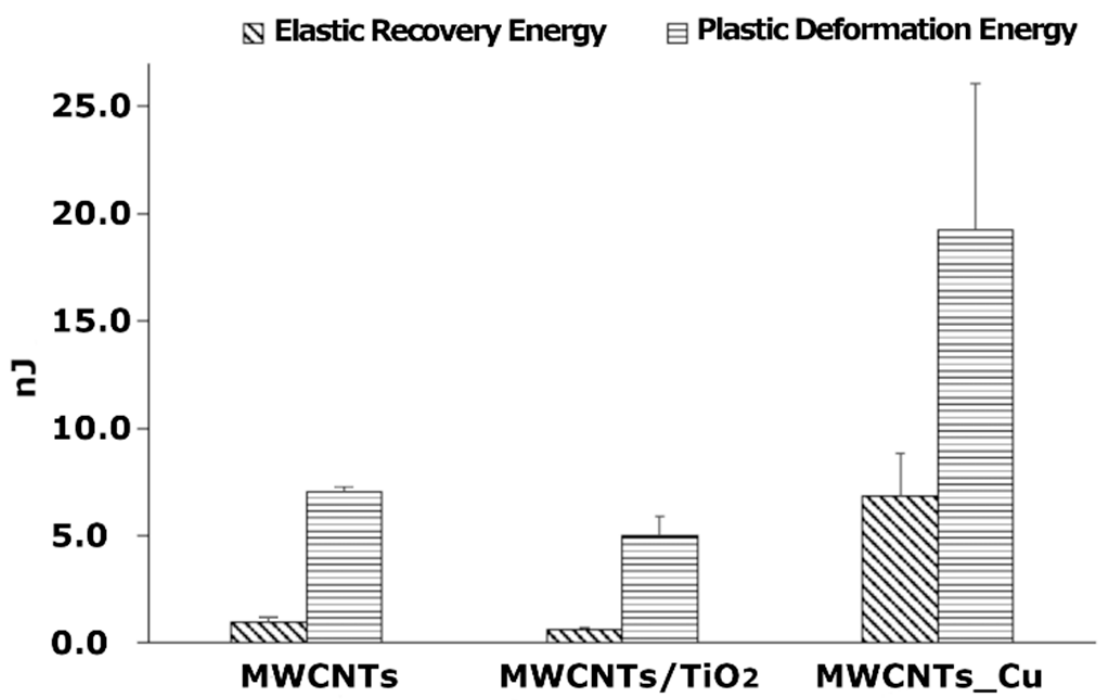

Figure 6. The comparison of plastic deformation and elastic energy for the tested coatings.

Other crucial parameters, further explaining mechanical properties of the MWCNTs, MWCNTs $/ \mathrm{TiO}_{2}$, and MWCNTs_Cu, are the ratio of the nanohardness to reduced elastic modulus $\left(\mathrm{H} / \mathrm{E}_{\mathrm{r}}\right)$, which shows the coating ability to accommodate substrate deflections under load (the coating endurance for chipping off under substrate bending), and the yield pressure $\left(\mathrm{H}^{3} / \mathrm{E}_{\mathrm{r}}^{2}\right)$, determining the resistance to plastic deformation under the nanoindenter probe load (the distortion of the coating material during nanoindentation test), as previously discussed in [47] for the Ti alloy. The addition of nanoceramics and nanometals to the MWCNTs coating improves its ability to accommodate the substrate deformation under applied load as the $\mathrm{H} / \mathrm{E}_{\mathrm{r}}$ parameter for both composite coatings is higher than that of the MWCNTs as illustrated in Figure 7A. In particular, the resistance to plastic deformation was significantly increased for coating implemented with hard ceramic nanotitania particles. 
A

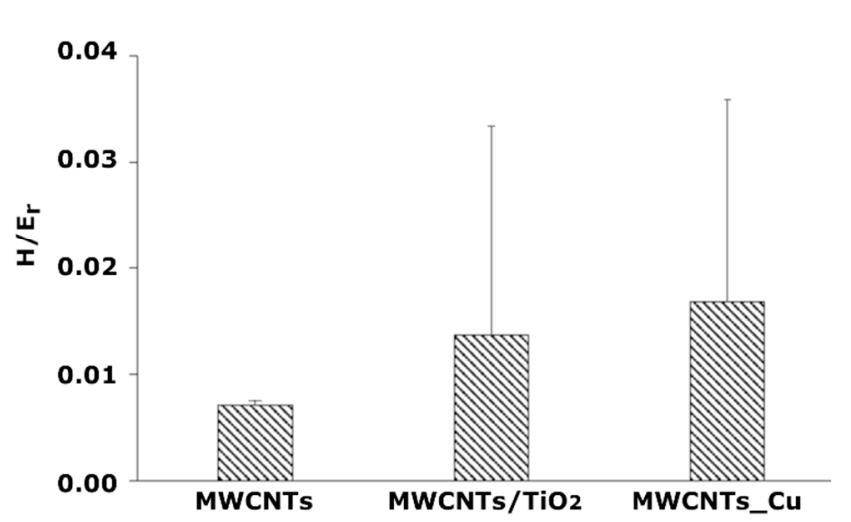

B

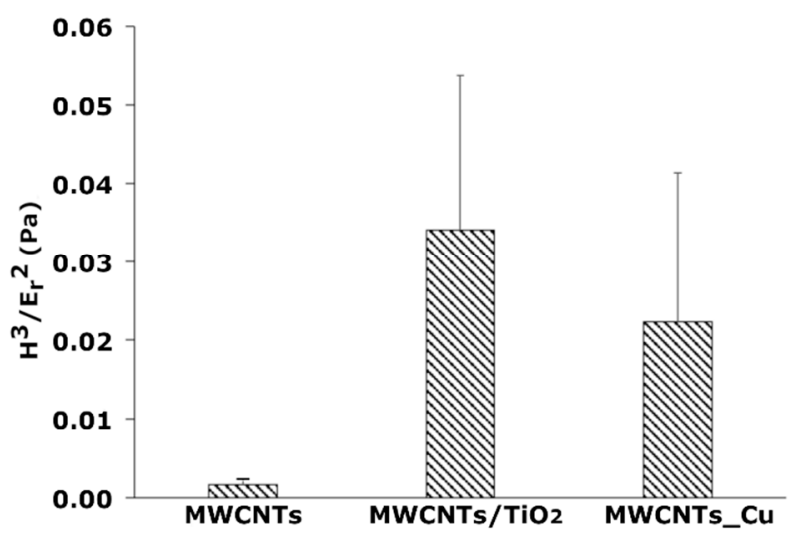

Figure 7. The diagrams for the $\mathrm{H} / \mathrm{E}_{\mathrm{r}}(\mathbf{A})$ and the $\mathrm{H}^{3} / \mathrm{E}_{\mathrm{r}}^{2}$ parameter (B), calculated for the $\mathrm{MWCNTs}, \mathrm{MWCNTs}^{2} \mathrm{TiO} 2$ bi-layer, and the MWCNTs_Cu dispersion coating, examined under indentation load of $10 \mathrm{mN}$.

Figure 7B shows the best ability to resist plastic deformation under nanoindenter tip load for the MWCNTs/ $\mathrm{TiO}_{2}$ coating, as also demonstrated in Figure 6, where the same coating was the least plastically deformed. The MWCNTs_Cu coating was significantly less susceptible to plastic deformation under nanoindenter tip action (Figure 7B) than the MWCNTs coating with the $\mathrm{TiO}_{2}$ addition. Figure 6 shows the MWCNTs_Cu coating as the most elastically deformed during the nanoindentation test (the coating partially returned to its shape).

\section{Discussion}

The results can be discussed in two aspects. At first, the change in surface properties due to surface modification by either of the two tested coatings can be attributed to different phenomena and determinants. Secondly, the influence of substrate surface on observed topography and mechanical appearance can be considered. To summarize, two variables, the coating microstructure and composition, and substrate composition are two variables to discuss.

The ceramic-carbon coating has roughness greater than the MWCNTs layer (Figures 1 and 2, and Table 2). It is a hybrid coating with inner CNTs and an outer titania layer. Highly rough topography is observed (Figure 3) with many separated nanoparticles of titanium dioxide or their aggregates. Figure 4 justifies the real presence of titanium in the layer. Unfortunately, the authors have failed to obtain a homogenous coating by simultaneous deposition of MWCNTs and $\mathrm{TiO}_{2}$. On the other hand, the design and preparation of such bi-layer coatings on the titanium alloys appears a highly fruitful strategy if the inner layer is elastic (soft) and allows cracks to bridge, deviate or passivate, or absorb energy [52]. In other words, the layered structure (hybrid or sandwich structure) of a coating permits the simultaneous creation of the hard outer layer and the elastic, impact and high stress absorbent, resistant-to-damage inner layer. The last phenomenon results from preventing the occurrence of cracks and, in particular, their movement across the whole coating. There are opinions [53] that such a two-stage deposition process offers more flexibility in the composition of the coatings, but as it has been shown here, the EPD mechanisms are in such a case becoming complex, and to develop the coatings with optimal characteristics is difficult and needs several attempts, which will be made in the future for the most promising $\mathrm{MWCNTs} / \mathrm{TiO}_{2}$. In particular, an aggregation of nanoparticles is an unnecessary phenomenon that should be avoided or eliminated by chemical functionalization, solvent exchange, ultrasonication, or in another way [54,55].

The composite carbon-metal coating also has roughness greater than the MWCNTs coating (Table 2), but lower than that of the hybrid coating, and a more homogenous surface (Figure 3). The $\mathrm{Cu}$ nanoparticles are well dispersed in the matrix, and in such a manner 
they do not seriously contribute to the roughness. Figure 4 proves the real presence of copper in the layer.

When comparing the mechanical values for both tested coatings, the difference between hybrid MWCNTs-titania and composite MWCNTs_Cu coatings is apparent. The MWCNTs-oxide coating has greater hardness and Young's modulus than the carbon nanotube-metal coating. The first coating may be then considered in such applications in which the coating opposes high stresses and must be resistant to wear or cracking. The second coating, which includes antibacterial metal, can be recommended for particular coatings that should actively kill bacteria in their neighborhood [56], but with no excessive loads during surgery and further use of the implant.

The obtained results are similar to those previously obtained for Ti alloy [47], but to some extent only. For hybrid coating, the network of carbon nanotubes forms an elastic sub-layer that immobilizes the titania nanoparticles; in such a way, the hardness is similar to that of titanium dioxide. Such a formula gives hard coating, but presumably, due to nanoform and the existence of inner layer, it is also not prone to brittle cracking which appears often in the case of ceramic coatings. For composite coating, low hardness can be attributed to small, relatively soft metallic nanoparticles, well-positioned in the CNTs network. Therefore, in this case, they do not play an important role in creating hardness and strength.

As concerns Young's modulus value, it is close to the values observed for human bones: about $19 \mathrm{GPa}$ for cortical bone [57] and $6 \mathrm{GPa}$ for mature bone [58]. It may be expected that the hardness and Young's modulus either both increase or decrease as observed for CNTs-Ti6Al4V nanocomposite [59], MWCNTs-graphene-Al alloy [60], and HAp-CNTs on Ti [61].

The mechanical behavior can also be characterized by the elastic recovery energy, plastic deformation energy, a ratio of the nanohardness to the reduced elastic modulus $\left(\mathrm{H} / \mathrm{E}_{\mathrm{r}}\right)$, and the yield pressure $\left(\mathrm{H}^{3} / \mathrm{E}_{\mathrm{r}}^{2}\right)$. The deep plastic deformation during the nanoindentation test is, based on these results, observed for composite coating MWCNT_Cu.

The thickness of obtained coatings has not been here determined, but comparing to previous reports and applied voltage and time of deposition it is likely to be in the range of 50-80 $\mu \mathrm{m}$ [53]. Therefore, the nanoindentation results have not been influenced by the substrate.

Finally, it is interesting to assess whether the chemical and phase composition of a substrate may affect the mechanical appearance after deposition of coatings at the same conditions. The appropriate values are listed in Table 4. Considering the above results, almost all of them can be satisfactorily explained. In particular, the higher hardness, the greater Young's modulus. However, it is true only for the same substrate, either titanium or its alloy, and with the exception of MWCNTs-titania coating, likely due to the highly nonhomogeneous surface. More importantly, the chemical and phase composition for substrate seems to play a significant role. For titanium substrate, the MWCNTs-oxide coating has a greater hardness, Young's modulus, and lower indent depth than the MWCNTsnanocopper coating. For Ti alloy, the opposite relation was observed. These results might be considered as not fully reliable as the standard deviations approach even $30-50 \%$. Therefore, this issue needs further experiments. On the other side, observed phenomena can be explained by: (i) deposition of coating dependent on surface characteristics, and (ii) interaction between nanoindenter tip and substrate (size effect) [62].

The mechanical properties of hybrid carbon-ceramic coatings on both substrates are, within the limits of an experimental error, close to one another. It is acceptable, as the MWCNTs are deposited in both cases as inner layers, and become adherent to the surface by chemical bonding and physical adsorption. They both depend on surface chemical composition [18]. The weaker coating observed on the Ti alloy as a substrate may be attributed to a general tendency to form more homogenous coatings on pure metals than on alloys with their chemical segregation and two or more phase constituents. The elastic and plastic resistances indicate that the outer titania layer is strong and brittle, which may 
be expected for the ceramic layer. The opposite effect is observed for composite coatings. It is postulated that, in this case, the much harder surface for coating deposited on the alloy, as compared to the pure titanium, may contribute to the hardness value at relatively deep indents.

Table 4. Comparison of mechanical properties of two coatings deposited on different substrates: Ti (present work) and Ti13Nb13Zr (previous research [47]).

\begin{tabular}{|c|c|c|c|c|c|c|c|c|}
\hline Coating & Substrate & $S_{a}(\mu \mathrm{m})$ & H (GPa) & $\mathrm{E}(\mathrm{GPa})$ & $h_{\max }(\mu \mathrm{m})$ & PDE (nJ) & ERE (nJ) & $\mathrm{H} / \mathrm{E}_{\mathrm{r}}$ 10(6) \\
\hline MWCNTs & $\mathrm{Ti}$ & 0.29 & 0.032 & 3.41 & 3.58 & 7.06 & 0.958 & 7.1 \\
\hline MWCNTs & Ti13Nb13Zr & 0.34 & 0.101 & 14.17 & 2.07 & 3.88 & 0.378 & 5.3 \\
\hline MWCNTs_TiO 2 & $\mathrm{Ti}$ & 0.56 & 0.183 & 10.11 & 1.55 & 5.01 & 0.644 & 13.7 \\
\hline MWCNTs_TiO 2 & Ti13Zr13Nb & 0.65 & 0.137 & 7.69 & 1.81 & 5.87 & 0.722 & 13.1 \\
\hline $\mathrm{MWCNTs} / \mathrm{Cu}$ & $\mathrm{Ti}$ & 0.36 & 0.079 & 3.51 & 2.55 & 19.23 & 6.821 & 16.8 \\
\hline MWCNTs/Cu & Ti13Zr13Nb & 0.41 & 0.213 & 10.83 & 1.43 & 3.53 & 0.688 & 14.7 \\
\hline
\end{tabular}

Table 4 shows the mechanical parameters of coatings obtained on two different substrates. The values to compare the previous results to those obtained in the present work have not been found in the literature, except the MWCNTs coating. The elastic modulus of MWCNTs ranged between 270 and 2400 GPa [55], while in other work it was 467-507 GPa [63]. For $\mathrm{TiO}_{2}$ reinforced with CNTs composites [64], hardness was about $250 \mathrm{GPa}$ and elastic modulus about $190 \mathrm{GPa}$, and for fluorapatite- $\mathrm{TiO}_{2}$ and fluorapatite$\mathrm{TiO}_{2}-\mathrm{CNT}(\mathrm{Cu})$ coatings hardness was only 0.72 and $0.58 \mathrm{GPa}$, and Young's modulus 14.5 and 19.3 GPa, respectively [65]. As regards composites with carbon nanotubes and copper, hardness was determined as above $600 \mathrm{GPa}$ for CNTs-1Cu composites in [66], hardness was of 1.1-1.4 GPa and Young's modulus 96-108 GPa in CNTs-Cu nanocomposites [67], and $\mathrm{H}$ of $85-96 \mathrm{MPa}$ and $\mathrm{E}$ of 9-10 GPa in other work of the same team was reported [68], copper-based hybrid nanocomposites with 4 wt. pct. of SiC and MWCNTs showed hardness increased from 0.96 to $1.61 \mathrm{GPa}$, and Young's modulus from 98 to $120 \mathrm{GPa}$ for pure copper and nanocomposite, respectively [69], for Cu-10MWCNTs the hardness was about 1 GPa and Young's modulus about $100 \mathrm{GPa}$ in [70] and for HAp-CNTs (20 wt. pct.) the hardness and Young's modulus were $13.3 \mathrm{GPa}$ and $189.5 \mathrm{GPa}$, respectively [71]. Here, determined values of hardness and Young's modulus are lower than the above-reported values which may be attributed to the specific microstructure of tested coatings, relatively thick and containing not closely packed carbon nanotubes.

Figure 8 shows the comparison between the yield pressure parameter for each coating deposited, both on Ti and Ti alloy substrate. It could be observed that also, in this case, different relationships for coatings deposited either on Ti or Ti alloy appear. For Ti alloy, the nanocopper addition improved the resistance to plastic deformation under indenter tip load, but it also caused cracking in the MWCNTs coating. For Ti substrate, the cracks were invisible, but the MWCNTs-nanocopper coating achieved a lower yield pressure parameter than for the MWCNTs-titania coating. This shows that the substrate affects the properties of deposited coatings.

Both coatings have been developed for the medical implantology field, for long-term titanium implants. It is well-known that high mechanical stresses may appear during implantation surgery. Therefore, the coatings need to be both elastic and resistant to plastic deformation, well adjacent to the titanium surface, and possess Young's modulus close to that of a bone. The present results show that the MWCNTs-titania coating, never before investigated at the present setting, is especially plausible for such application. 


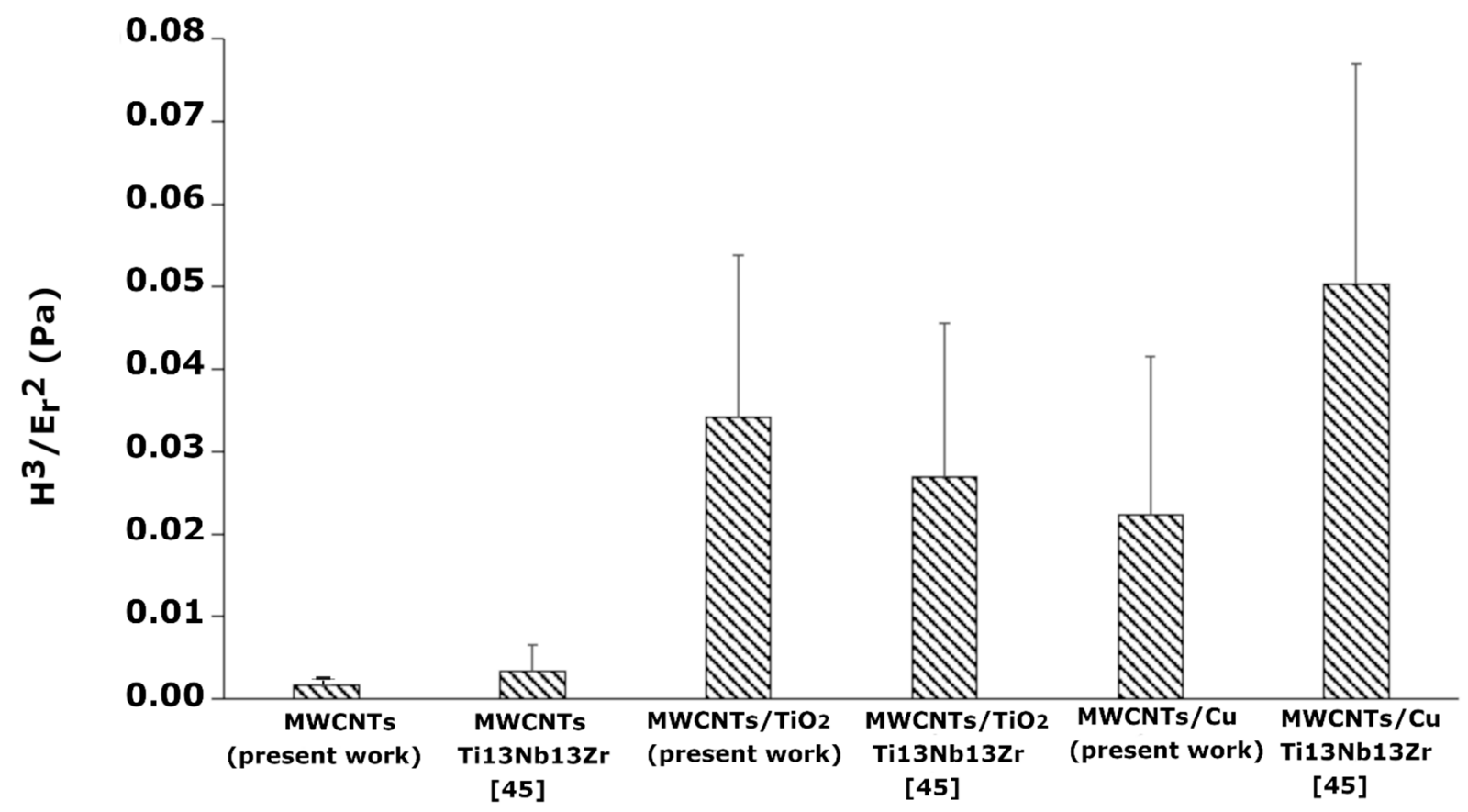

Figure 8. The diagram comparing the $\mathrm{H}^{3} / \mathrm{Er}^{2}$ parameter for the MWCNTs, MWCNTs/TiO 2 bi-layer, and the MWCNTs_Cu dispersion coating deposited on $\mathrm{Ti}$ (present work) and Ti13Nb13Zr [47], examined under indentation load of $10 \mathrm{mN}$.

\section{Conclusions}

The best mechanical, plastic, and elastic properties were achieved for the multi-wall carbon nanotubes coating combined with titania particles. This coating possesses the highest Young's modulus, close to that of natural human bone, and the best resistance to plastic deformation so that it substantially improved the capability of the MWCNTs coating to accommodate stresses appearing under applied load during surgery or further use of an implant. The addition of nanocopper to the MWCNTs coating made the material more susceptible to plastic deformation; nevertheless, it also improved the MWCNTs coating resistance to chipping off under deflection loading.

There is a general rule that more homogenous coatings form on pure metals than on their alloys. The latter materials are more complex in terms of chemical and phase composition, but also demonstrate a much harder surface compared to the pure titanium. Therefore, the observed different mechanical behavior of coatings on the different substrates is related to the difference in surface composition of the substrate and its influence on the EDP process, mainly on the adhesion of the coating.

The applications of obtained coatings may be different, but they can be considered plausible as coatings for implants for orthopedic applications. Such coatings need to be both elastic and resistant to relatively high stresses during implantation surgery and possess Young's modulus close to that of a bone. From a mechanical point of view, the tested coatings, in particular MWCNTs-titania nanocomposite structure, can be particularly considered useful for medical implantology if biological properties become appropriate.

Author Contributions: Conceptualization, D.R.-W. and B.M.-M.; methodology, D.R.-W. and B.M.-M.; software, D.R.-W.; validation, D.R.-W., B.M.-M., A.Z., and B.J.J.; formal analysis, D.R.-W.; investigation, D.R.-W. and B.M.-M.; resources, D.R.-W.; writing-original draft preparation, D.R.-W. and A.Z.; writing-review and editing, A.Z. and B.J.J.; visualization, D.R.-W.; supervision, A.Z.; and project administration, B.M.-M. All authors have read and agreed to the published version of the manuscript.

Funding: This research received no external funding. 
Institutional Review Board Statement: Not applicable.

Informed Consent Statement: Not applicable.

Data Availability Statement: Not applicable.

Acknowledgments: We would like to express our sincere gratitude to Michał Bartmański for his support in carrying out the nanoindentation experiment and Grzegorz Gajowiec for SEM analysis, Dawid Chojnowski-Team Leader Microscopes from Keyence International (Belgium) NV/SA for sharing microscope VHX Keyence equipment, and support in preparing data to the above publication, Aleksandra Kowalska and Justyna Kiljan for their immense support in preparing coatings, and Patrycja Kowalik_Product Manager from Technolutions for sharing nanoindentation tester $\mathrm{NHT}^{3}$.

Conflicts of Interest: The authors declare no conflict of interest.

\section{References}

1. Manikandan, N.; Suresh Kumar, V.P.; Siva Murugan, S.; Rathis, G.; Vishnu Saran, K.; Shabariganesh, T.K. Carbon nanotubes and their properties-The review. Mater. Today Proc. 2021, 2-5, in press. [CrossRef]

2. Anzar, N.; Hasan, R.; Tyagi, M.; Yadav, N.; Narang, J. Carbon nanotube-A review on synthesis, properties and plethora of applications in the field of biomedical science. Sens. Int. 2020, 1, 100003. [CrossRef]

3. Rathinavel, S.; Priyadharshini, K.; Panda, D. A review on carbon nanotube: An overview of synthesis, properties, functionalization, characterization, and the application. Mater. Sci. Eng. B 2021, 268, 115095. [CrossRef]

4. Tao, F.; Liu, Y.; Ren, X.; Jiang, A.; Wei, H.; Zhai, X.; Wang, F.; Stock, H.-R.; Wen, S.; Ren, F. Carbon nanotube-based nanomaterials for high-performance sodium-ion batteries: Recent advances and perspectives. J. Alloys Compd. 2021, 873, 159742. [CrossRef]

5. Gao, X.; Yin, W.; Liu, X. Carbon nanotubes-based electrode for Zn ion batteries. Mater. Res. Bull. 2021, 138, 111246. [CrossRef]

6. Caoduro, C.; Hervouet, E.; Girard-Thernier, C.; Gharbi, T.; Boulahdour, H.; Delage-Mourroux, R.; Pudlo, M. Carbon nanotubes as gene carriers: Focus on internalization pathways related to functionalization and properties. Acta Biomater. 2017, 49, 36-44. [CrossRef]

7. Ding, F.; Ren, P.; Wang, G.; Wu, S.; Du, Y.; Zou, X. Hollow cellulose-carbon nanotubes composite beads with aligned porous structure for fast methylene blue adsorption. Int. J. Biol. Macromol. 2021, 182, 750-759. [CrossRef] [PubMed]

8. Gao, X.; Xue, W.; Ye, W.; Zhao, R.; Ma, X.; He, D. Large-scale synthesis of nitrogen doped graphene/carbon nanotube composites by solid-state pyrolysis of nickel phthalocyanine and its synergistic effect for microwave absorption properties. Mater. Lett. 2021, 294, 129767. [CrossRef]

9. Grądzka, E.; Dłużewski, P.; Wigda, I.; Wysocka-Żołopa, M.; Winkler, K. Formation and electrochemical properties of multiwalled carbon nanotubes and polypyrrole composite with (n-Oc4N)Br binder. Synth. Met. 2021, 272, 116661. [CrossRef]

10. Rajitha, K.; Mohana, K.N.S.; Hegde, M.B.; Nayak, S.R.; Swamy, N.K. Fabrication of ZnO/rGO and ZnO/MWCNT nanohybrids to reinforce the anticorrosion performance of polyurethane coating. FlatChem 2020, 24, 100208. [CrossRef]

11. Yakovlev, G.; Pervushin, G.; Maeva, I.; Keriene, J.; Pudov, I.; Shaybadullina, A.; Buryanov, A.; Korzhenko, A.; Senkov, S. Modification of Construction Materials with Multi-Walled Carbon Nanotubes. Procedia Eng. 2013, 57, 407-413. [CrossRef]

12. Kim, G.M.; Nam, I.W.; Yang, B.; Yoon, H.N.; Lee, H.K.; Park, S. Carbon nanotube (CNT) incorporated cementitious composites for functional construction materials: The state of the art. Compos. Struct. 2019, 227, 111244. [CrossRef]

13. Preethi, K.; Raju, T.N.; Shivappa, H.A.; Shashidhar, S.; Nagral, M. Processing, microstructure, hardness and wear behavior of carbon nanotube particulates reinforced Al6061 alloy composites. Mater. Today Proc. 2021, in press. [CrossRef]

14. Chen, X.; Liu, H.; Hu, D.; Liu, H.; Ma, W. Recent advances in carbon nanotubes-based microwave absorbing composites. Ceram. Int. 2021, in press. [CrossRef]

15. Garg, A.; Chalak, H.D.; Belarbi, M.-O.; Zenkour, A.M.; Sahoo, R. Estimation of carbon nanotubes and their applications as reinforcing composite materials-an engineering review. Compos. Struct. 2021, 272, 114234. [CrossRef]

16. Wesełucha-Birczyńska, A.; Stodolak-Zych, E.; Piś, W.; Długoń, E.; Benko, A.; Błażewicz, M. A model of adsorption of albumin on the implant surface titanium and titanium modified carbon coatings (MWCNT-EPD). 2D correlation analysis. J. Mol. Struct. 2016, 1124, 61-70. [CrossRef]

17. Kim, T.; Shin, D.; Lee, J.; Kim, S.J. Effect of layer-by-layer assembled carbon nanotube coatings on dropwise condensation heat transfer associated with non-condensable gas effect. Int. J. Heat Mass Transf. 2021, 175, 121345. [CrossRef]

18. Deng, J.; Pang, S.; Wang, C.; Ren, T. Biotribological properties of Ti-6Al-4V alloy treated with self-assembly multi-walled carbon nanotube coating. Surf. Coat. Technol. 2020, 382, 125169. [CrossRef]

19. Rice, D.; Rajwade, K.; Zuo, K.; Bansal, R.; Li, Q.; Garcia-Segura, S.; Perreault, F. Electrochemically-active carbon nanotube coatings for biofouling mitigation: Cleaning kinetics and energy consumption for cathodic and anodic regimes. J. Colloid Interface Sci. 2021, 603, 391-397. [CrossRef]

20. Szabó, A.; Nánai, L.; Tóth, Z.R.; Hernadi, K. Simplification of the CCVD method used in the growth of carbon nanotube forests on titanium substrate. Solid State Sci. 2021, 117, 106648. [CrossRef] 
21. Gopi, D.; Shinyjoy, E.; Sekar, M.; Surendiran, M.; Kavitha, L.; Sampath Kumar, T.S. Development of carbon nanotubes reinforced hydroxyapatite composite coatings on titanium by electrodeposition method. Corros. Sci. 2013, 73, 321-330. [CrossRef]

22. Pei, X.; Zeng, Y.; He, R.; Li, Z.; Tian, L.; Wang, J.; Wan, Q.; Li, X.; Bao, H. Single-walled carbon nanotubes/hydroxyapatite coatings on titanium obtained by electrochemical deposition. Appl. Surf. Sci. 2014, 295, 71-80. [CrossRef]

23. Devgan, S.; Sidhu, S.S. Surface modification of $\beta$-type titanium with multi-walled CNTs/ $\mu$-HAp powder mixed Electro Discharge Treatment process. Mater. Chem. Phys. 2020, 239, 122005. [CrossRef]

24. Gopi, D.; Shinyjoy, E.; Kavitha, L. Influence of ionic substitution in improving the biological property of carbon nanotubes reinforced hydroxyapatite composite coating on titanium for orthopedic applications. Ceram. Int. 2015, 41, 5454-5463. [CrossRef]

25. Chen, B.; Li, X.; Jia, Y.; Xu, L.; Liang, H.; Li, X.; Yang, J.; Li, C.; Yan, F. Fabrication of ternary hybrid of carbon nanotubes/graphene oxide/MoS2 and its enhancement on the tribological properties of epoxy composite coatings. Compos. Part A Appl. Sci. Manuf. 2018, 115, 157-165. [CrossRef]

26. Maleki-Ghaleh, H.; Khalil-Allafi, J. Characterization, mechanical and in vitro biological behavior of hydroxyapatite-titaniumcarbon nanotube composite coatings deposited on NiTi alloy by electrophoretic deposition. Surf. Coatings Technol. 2019, 363, 179-190. [CrossRef]

27. Maho, A.; Detriche, S.; Delhalle, J.; Mekhalif, Z. Sol-gel synthesis of tantalum oxide and phosphonic acid-modified carbon nanotubes composite coatings on titanium surfaces. Mater. Sci. Eng. C 2013, 33, 2686-2697. [CrossRef] [PubMed]

28. Park, J.E.; Park, I.-S.; Neupane, M.P.; Bae, T.-S.; Lee, M.-H. Effects of a carbon nanotube-collagen coating on a titanium surface on osteoblast growth. Appl. Surf. Sci. 2014, 292, 828-836. [CrossRef]

29. Gizawy, M.A.; Shamsel-Din, H.A.; Abdelmonem, I.M.; Ibrahim, M.I.A.; Mohamed, L.A.; Metwally, E. Synthesis of chitosan-acrylic acid/multiwalled carbon nanotubes composite for theranostic 47Sc separation from neutron irradiated titanium target. Int. J. Biol. Macromol. 2020, 163, 79-86. [CrossRef]

30. Marchewka, J.; Jeleń, P.; Długoń, E.; Sitarz, M.; Błażewicz, M. Spectroscopic investigation of the carbon nanotubes and polysiloxane coatings on titanium surface. J. Mol. Struct. 2020, 1212, 128176. [CrossRef]

31. Ye, Z.; Li, J.; Liu, L.; Ma, F.; Zhao, B.; Wang, X. Microstructure and wear performance enhancement of carbon nanotubes reinforced composite coatings fabricated by laser cladding on titanium alloy. Opt. Laser Technol. 2021, 139, 106957. [CrossRef]

32. Hussain, S.; Erikson, H.; Kongi, N.; Tarre, A.; Ritslaid, P.; Rähn, M.; Matisen, L.; Merisalu, M.; Sammelselg, V.; Tammeveski, K. Pt nanoparticles sputter-deposited on $\mathrm{TiO}_{2} /$ MWCNT composites prepared by atomic layer deposition: Improved electrocatalytic activity towards the oxygen reduction reaction and durability in acid media. Int. J. Hydrogen Energy 2018, 43, 4967-4977. [CrossRef]

33. Kayang, K.W.; Nyankson, E.; Efavi, J.K.; Apalangya, V.A.; Adetunji, B.I.; Gebreyesus, G.; Tia, R.; Abavare, E.K.K.; OnwonaAgyeman, B.; Yaya, A. A comparative study of the interaction of nickel, titanium, palladium, and gold metals with single-walled carbon nanotubes: A DFT approach. Results Phys. 2019, 12, 2100-2106. [CrossRef]

34. Saravanakumar, K.; Mariadoss, A.V.A.; Sathiyaseelan, A.; Wang, M.-H. Synthesis and characterization of nano-chitosan capped gold nanoparticles with multifunctional bioactive properties. Int. J. Biol. Macromol. 2020, 165, 747-757. [CrossRef]

35. Yokoyama, K.; Ichiki, A. Nano-size dependence in the adsorption by the SARS-CoV-2 spike protein over gold colloid. Colloids Surfaces A Physicochem. Eng. Asp. 2021, 615, 126275. [CrossRef]

36. Yokoyama, K.; Ichiki, A. Spectroscopic investigation on the affinity of SARS-CoV-2 spike protein to gold nano-particles. Colloid Interface Sci. Commun. 2021, 40, 100356. [CrossRef] [PubMed]

37. Dziaduszewska, M.; Wekwejt, M.; Bartmański, M.; Pałubicka, A.; Gajowiec, G.; Seramak, T.; Osyczka, A.M.; Zieliński, A. The Effect of Surface Modification of Ti13Zr13Nb Alloy on Adhesion of Antibiotic and Nanosilver-Loaded Bone Cement Coatings Dedicated for Application as Spacers. Materials 2019, 12, 2964. [CrossRef] [PubMed]

38. Razmara, P.; Imbery, J.J.; Koide, E.; Helbing, C.C.; Wiseman, S.B.; Gauthier, P.T.; Bray, D.F.; Needham, M.; Haight, T.; Zovoilis, A.; et al. Mechanism of copper nanoparticle toxicity in rainbow trout olfactory mucosa. Environ. Pollut. 2021, 284, 117141. [CrossRef]

39. Zhang, J.; Zhu, S.; Song, K.; Wang, Z.; Han, Z.; Zhao, K.; Fan, Z.; Zhou, X.; Zhang, Q. 3D reduced graphene oxide hybrid nano-copper scaffolds with a high antibacterial performance. Mater. Lett. 2020, 267, 127527. [CrossRef]

40. Ahmed, F.; Faisal, S.M.; Ahmed, A.; Husain, Q. Beta galactosidase mediated bio-enzymatically synthesized nano-gold with aggrandized cytotoxic potential against pathogenic bacteria and cancer cells. J. Photochem. Photobiol. B Biol. 2020, $209,111923$. [CrossRef] [PubMed]

41. Kumar, P. Nano-TiO 2 Doped Chitosan Scaffold for the Bone Tissue Engineering Applications. Int. J. Biomater. 2018, $2018,6576157$. [CrossRef] [PubMed]

42. Lephuthing, S.S.; Okoro, A.M.; Ige, O.O.; Olubambi, P.A. Comparison of dispersion methods of multi-walled carbon nanotubes in titanium oxide. Mater. Today Proc. 2020, 28, 704-709. [CrossRef]

43. Kaushik, P.; Eliáš, M.; Michalička, J.; Hegemann, D.; Pytlíček, Z.; Nečas, D.; Zajíčková, L. Atomic layer deposition of titanium dioxide on multi-walled carbon nanotubes for ammonia gas sensing. Surf. Coatings Technol. 2019, 370, 235-243. [CrossRef]

44. Bartmanski, M.; Zielinski, A.; Jazdzewska, M.; Głodowska, J.; Kalka, P. Effects of electrophoretic deposition times and nanotubular oxide surfaces on properties of the nanohydroxyapatite/nanocopper coating on the Ti13Zr13Nb alloy. Ceram. Int. 2019, 45, 20002-20010. [CrossRef] 
45. Bartmański, M.; Pawłowski, Ł.; Strugała, G.; Mielewczyk-Gryń, A.; Zieliński, A. Properties of Nanohydroxyapatite Coatings Doped with Nanocopper, Obtained by Electrophoretic Deposition on Ti13Zr13Nb Alloy. Materials 2019, 12, 3741. [CrossRef] [PubMed]

46. Kruk, T.; Gołda-Cępa, M.; Szczepanowicz, K.; Szyk-Warszyńska, L.; Brzychczy-Włoch, M.; Kotarba, A.; Warszyński, P. Nanocomposite multifunctional polyelectrolyte thin films with copper nanoparticles as the antimicrobial coatings. Colloids Surfaces $B$ Biointerfaces 2019, 181, 112-118. [CrossRef]

47. Rogala-Wielgus, D.; Majkowska-Marzec, B.; Zieliński, A.; Bartmański, M.; Bartosewicz, B. Mechanical Behavior of Bi-Layer and Dispersion Coatings Composed of Several Nanostructures on Ti13Nb13Zr Alloy. Materials 2021, 14, 2905. [CrossRef]

48. Goyal, R.K.; Tiwari, A.N.; Negi, Y.S. Microhardness of PEEK/ceramic micro- and nanocomposites: Correlation with Halpin-Tsai model. Mater. Sci. Eng. A 2008, 491, 230-236. [CrossRef]

49. Adegbenjo, A.O.; Obadele, B.A.; Olubambi, P.A. Densification, hardness and tribological characteristics of MWCNTs reinforced Ti6Al4V compacts consolidated by spark plasma sintering. J. Alloys Compd. 2018, 749, 818-833. [CrossRef]

50. Ramganesh, V.; Ananth Kumar, M.; Mini, K.; Vignesh, V.; Karthikeyan, R. Effect of nano TiO2-epoxy composite in bond strength and corrosion resistance of rebar embedded in micro-silica modified concrete. J. Phys. Conf. Ser. 2020, 1706, 012122. [CrossRef]

51. Kaczmar, J.W.; Granat, K.; Kurzawa, A.; Grodzka, E. Physical Properties of Copper Based MMC Strengthened with Alumina. Arch. Foundry Eng. 2014, 14, 85-90. [CrossRef]

52. Bai, H.; Zhong, L.; Kang, L.; Liu, J.; Zhuang, W.; Lv, Z.; Xu, Y. A review on wear-resistant coating with high hardness and high toughness on the surface of titanium alloy. J. Alloys Compd. 2021, 882, 160645. [CrossRef]

53. Atiq Ur Rehman, M.; Chen, Q.; Braem, A.; Shaffer, M.S.P.; Boccaccini, A.R. Electrophoretic deposition of carbon nanotubes: Recent progress and remaining challenges. Int. Mater. Rev. 2020, 1-30. [CrossRef]

54. Castro-Muñoz, R.; Ahmad, M.Z.; Fíla, V. Tuning of Nano-Based Materials for Embedding Into Low-Permeability Polyimides for a Featured Gas Separation. Front. Chem. 2020, 7, 897. [CrossRef] [PubMed]

55. Soni, S.K.; Thomas, B.; Kar, V.R. A comprehensive review on CNTs and CNT-reinforced composites: Syntheses, characteristics and applications. Mater. Today Commun. 2020, 25, 101546. [CrossRef]

56. Dziaduszewska, M.; Zieliński, A. Structural and Material Determinants Influencing the Behavior of Porous Ti and Its Alloys Made by Additive Manufacturing Techniques for Biomedical Applications. Materials 2021, 14, 712. [CrossRef]

57. Fraczek-Szczypta, A.; Jantas, D.; Ciepiela, F.; Grzonka, J.; Bernasik, A.; Marzec, M. Carbon nanomaterials coatings-Properties and influence on nerve cells response. Diam. Relat. Mater. 2018, 84, 127-140. [CrossRef]

58. Byrne, D.P.; Lacroix, D.; Planell, J.A.; Kelly, D.J.; Prendergast, P.J. Simulation of tissue differentiation in a scaffold as a function of porosity, Young's modulus and dissolution rate: Application of mechanobiological models in tissue engineering. Biomaterials 2007, 28, 5544-5554. [CrossRef]

59. Okoro, A.M.; Machaka, R.; Lephuthing, S.S.; Oke, S.R.; Awotunde, M.A.; Olubambi, P.A. Nanoindentation studies of the mechanical behaviours of spark plasma sintered multiwall carbon nanotubes reinforced Ti6Al4V nanocomposites. Mater. Sci. Eng. A 2019, 765, 138320. [CrossRef]

60. Kumar, V.; Kempaiah, U.N.; Shivasharanayyaswamy; Bopanna, S.B. Nanoindentation studies on multiwalled carbon nanotubes/graphene reinforced aluminium alloy 6061 nanocomposites. Mater. Today Proc. 2020, 45, 202-206. [CrossRef]

61. Hahn, B.; Lee, J.-M.; Park, D.; Choi, J.; Ryu, J.; Yoon, W.; Lee, B.; Shin, D.; Kim, H. Mechanical and in vitro biological performances of hydroxyapatite-carbon nanotube composite coatings deposited on Ti by aerosol deposition. Acta Biomater. 2009, 5, 3205-3214. [CrossRef]

62. Le Bourhis, E. Appendix 8: Instrumented Nanoindentation Applied to Thin Films. In Glass; Wiley-VCH Verlag GmbH \& Co. KGaA: Weinheim, Germany, 2007; pp. 291-309. [CrossRef]

63. Belhenini, S.; Labbaye, T.; Boulmer-Leborgne, C.; Kovacevic, E.; Tougui, A.; Dosseul, F. Elastic modulus measurements of vertically aligned multi walled carbon nanotubes carpets by using the nanoindentation technique. Mech. Res. Commun. 2017, 85, 16-20. [CrossRef]

64. Debalina, B.; Vaishakh, N.; Jagannatham, M.; Vasanthakumar, K.; Karthiselva, N.S.; Vinu, R.; Haridoss, P.; Bakshi, S.R. Effect of different nano-carbon reinforcements on microstructure and properties of $\mathrm{TiO}_{2}$ composites prepared by spark plasma sintering. Ceram. Int. 2016, 42, 14266-14277. [CrossRef]

65. Sasani, N.; Vahdati Khaki, J.; Mojtaba Zebarjad, S. Characterization and nanomechanical properties of novel dental implant coatings containing copper decorated-carbon nanotubes. J. Mech. Behav. Biomed. Mater. 2014, 37, 125-132. [CrossRef]

66. Tsai, P.-C.; Jeng, Y.-R.; Lee, J.-T.; Stachiv, I.; Sittner, P. Effects of carbon nanotube reinforcement and grain size refinement mechanical properties and wear behaviors of carbon nanotube/copper composites. Diam. Relat. Mater. 2017, 74, 197-204. [CrossRef]

67. Tsai, P.-C.; Jeng, Y.-R. Enhanced mechanical properties and viscoelastic characterizations of nanonecklace-reinforced carbon nanotube/copper composite films. Appl. Surf. Sci. 2015, 326, 131-138. [CrossRef]

68. Tsai, P.-C.; Jeng, Y.-R. Experimental and numerical investigation into the effect of carbon nanotube buckling on the reinforcement of CNT/Cu composites. Compos. Sci. Technol. 2013, 79, 28-34. [CrossRef]

69. Mallikarjuna, H.M.; Ramesh, C.S.; Koppad, P.G.; Keshavamurthy, R.; Sethuram, D. Nanoindentation and wear behaviour of copper based hybrid composites reinforced with SiC and MWCNTs synthesized by spark plasma sintering. Vacuum 2017, 145, 320-333. [CrossRef] 
70. Nayan, N.; Shukla, A.K.; Chandran, P.; Bakshi, S.R.; Murty, S.V.S.N.; Pant, B.; Venkitakrishnan, P.V. Processing and characterization of spark plasma sintered copper/carbon nanotube composites. Mater. Sci. Eng. A 2017, 682, 229-237. [CrossRef]

71. Chen, Y.; Zhang, Y.Q.; Zhang, T.H.; Gan, C.H.; Zheng, C.Y.; Yu, G. Carbon nanotube reinforced hydroxyapatite composite coatings produced through laser surface alloying. Carbon N. Y. 2006, 44, 37-45. [CrossRef] 